\title{
NEČASOVÁ, Denisa: Obrazy nepř́itele v Československu 1948 - 1956. Praha : Lidové noviny, 2020. 235 s. ISBN 978-80-7422-688-5
}

\section{DOI: https://doi.org/10.24040/ahn.2020.23.02.271-276}

Začiatkom leta tohto roku vyšla v českom vydavatel'stve Lidové noviny monografia Obrazy neprítele v Československu 1948 - 1956. Koncept nepriatel'a je čoraz častejšie pertraktovanou témou vo verejnom, politickom, mediálnom či všeobecne spoločenskom diskurze, ale nielen tam. Stála aktualizácia vedeckovýskumného zamerania zvyšuje frekvenciu výskytu aj atraktivitu danej problematiky. Predmet záujmu pochádzajúci zo sociokultúrnej a politickej oblasti má široké, možno povedat' transdisciplinárne pole pôsobnosti. Je súčast'ou histórie, sociológie, politických vied, mediálnych štúdií a v neposlednom rade presahuje až k sociopragmatickým a kognitívnolingvistickým analýzam. To, že motív nepriatel'a netreba hl'adat' iba v aktuálnych kontextoch rasovej nenávisti, náboženskej, sexuálnej, ekologickej alebo genderovej intolerancie, resp. v celkovo sa prehlbujúcej homofóbii ukazuje najnovšia publikácia Denisy Nečasovej.

Autorka pôsobí na Historickom ústave Filozofickej fakulty Masarykovej univerzity v Brne. Svoju vedeckovýskumnú pozornost' koncentruje na súčasné dejiny, kultúrne dejiny a gender problematiku, v rámci ktorých predstavila niekol'ko publikácií zasadených rovnako do prvej etapy budovania socializmu v Československu. ${ }^{1}$

Ako bolo vyššie naznačené, koncept nepriatel'a je imanentnou súčast’ou každej spoločnosti. Slúži k legitimizácii domáceho politicko-ideologického či hodnotového systému a podiel'a sa na formovaní pozitívneho obrazu subjektu, voči ktorému sa vymedzuje. Jeho existencia podporuje pocit vlastného bezpečia a nadradenosti, ked’že všetky negatíva, zlyhania a sklamania možno smerovat' k protipólu - k predstave fyzického či ideového oponenta, interpretovaného v rovine určujúci subjekt (v tomto prípade československá spoločnost') verzus obraz Druhého. Autorka pracuje s definíciou nepriatel'a, ktorého vníma ako „kulturně a sociálně konstruovanou diskurzivní figuru, která se proměňuje v závislosti na daném významovém, časovém i geografickém kontextu" (s. 12). Vo svojej najnovšej publikácii Nečasová zvolila metodologicko-metodický prístup kritickej analýzy diskurzu, vhodný kvôli zameraniu na analýzu mocenských, a to najmä asymetrických vzt'ahov v spoločnosti. Súvisiacim

\footnotetext{
1 Pozri: NEČASOVÁ, Denisa: Nový socialistický člověk. Československo 1948 - 1956. Brno : Host, 2018. 271 s.; NEČASOVÁ, Denisa: Buduj vlast - posílíš mír! : ženské hnutí v českých zemích 1945 - 1955. Brno : Matice moravská, 2011. 411 s.
} 
faktorom vyplývajúcim zo zapojenia kritickej analýzy diskurzu je možnost' sledovat' dis/kontinuitu vývinových a symbolických vzt'ahov. Pozitívom publikácie je kvalitne rozpracovaný poznámkový aparát úvodnej kapitoly, ktorý je na jednej strane dôkazom autorkinho rozhl'adu a erudovanosti, ale zároveň poskytuje výborný vstup do problematiky aj pre d'alších záujemcov. Nachádzajú sa v ňom odkazy na domáce i zahraničné zdroje k téme diskurzu a kritickej analýze diskurzu (diela klasikov akými sú M. Foucault, N. Fairclough, R. Wodaková, M. Meyer, C. Hardy a iní), k lingvistickým i sociologickým prácam tematizujúcim koncept nepriatel'a, resp. inakosti, ale aj k množstvu vedeckých či odborných publikácií zaoberajúcich sa kultúrnymi, historickými a politickými otázkami danej doby.

Vzhl’adom na široké portfólio výskumného materiálu, do ktorého sú zaradené periodiká od Rudého práva až po tematicky orientované noviny, archívne aj publikované pramene či dobové beletristické zdroje možno právom hovorit' o kompetentnom naplnení pojmu diskurz. Časové ohraničenie rokmi 1948 - 1956 autorka výstižne zdôvodňuje konštatovaním, že „obrazy neprítele hrají klíčovou roli ve formovaní moderního státního či národního celku a nabývají na důležitosti zejména v době revolucí a počátečních fází konstituování nových společností" (s. 203). V publikácii rozdelenej do piatich kapitol Nečasová v prvom rade približuje koncept nepriatel'a v teoretickej rovine. Vychádza z toho, že ide o „výsledek širokého a mnohovrstevnatého procesu reprezentace a kategorizace skutečnosti“ (s. 21), ktorý možno rozčlenit' do procesu pozostávajúceho z ôsmich stupňov. Sú to diferenciácia, dichotomizácia, hierarchizácia, homogenizácia, esencializácia, objektivizácia, dehumanizácia, a napokon démonizácia. Tento systematický stupňovitý proces konštrukcie nepriatel'a tvorí metodologický základ aplikovatel'ný na akýkol'vek výskum podobného charakteru od spoločenských stereotypov, analýzy jazykového obrazu sveta až po štúdium kolektívnej pamäti a iných kultúrno-historických aspektov. Jeho univerzálnost' je jedným z vel'kých prínosov v knihe D. Nečasovej, ktorá následne syntetizuje teoretické aspekty konceptualizácie nepriatel'a s konkretizovanými prípadmi v československých podmienkach. Jej ciel'om nie je komplexná prezentácia všetkých zaznamenaných nepriatel'ov, ktorí boli v čase formovania socialistického režimu značne diverzifikovaní. Zameriava sa preto na štyri typy vybrané v dôsledku ich kvantitatívnej frekvencie - buržoázia, kulak, katolícky kňaz a Spojené štáty americké.

Ked’že buržoázia, spoločne s USA, zastávala v pofebruárovom oficiálnom diskurze najdominantnejšie miesto, venuje jej autorka značný priestor. $\mathrm{V}$ úvode kapitoly polemizuje s rôznymi charakteristikami pojmu, pričom konštatuje, že jeho definičné pole je vymedzené iba vel'mi 
vágne. Jednotiacim prvkom v sémantickej rovine je najmä ideologicky reflektovaná príslušnost' ku kapitalizmu a stvárnenie buržoázie ako reakčného spoločenského živlu reprezentovaného najčastejšie továrnikmi, finančníkmi, predstavitel'mi politických strán a exilovými aktivistami. Vybraná sociálna skupina je vzt’ahovo prepojená s liberálnymi, často antisocialistickými hodnotami a myšlienkovými názormi, v rámci ktorých sa profiloval jej obraz v oficiálnom diskurze. Týmto spôsobom dochádzalo k napíňaniu legitimizujúcej funkcie nepriatel'a vzhl'adom k novo sa utvárajúcemu socialistickému zriadeniu. Predmetom analýzy bol aj proces s Miladou Horákovou, na ktorom Nečasová zdôrazňuje istú genderovú výnimku. Vo svojej práci poukázala na fakt, že v pozícii ideologického oponenta, či už kolektívneho alebo individuálneho, vystupujú primárne muži. Tiež si to možno všimnút' na dobových plagátoch tvoriacich ilustračný predel jednotlivých kapitol. Na príklade Milady Horákovej sú znázornené diskurzívne praktiky využívajúce aspekty feminity a s ňou spojené atribúty ako materstvo, súcit, jemnost' či poddajnost' preferované u socialistickej ženy, ktoré boli použité s ciel'om konštrukcie nepriatel'a explicitne popierajúceho tieto ideologické hodnoty. Zároveň je tu aplikovaný princíp dehumanizácie protivníka a M. Horáková sa v kontexte politického procesu zobrazuje ako odl'udštená postava.

Druhá kapitola venovaná osobnosti kulaka približuje koncept ideologického nepriatel'a situovaného na vidieku. Podobne, ako v prípade buržoázie, aj tu sa Nečasová musela vyrovnat's nejednotnou terminológiou a otázkou, kto bol v dobovom diskurze kulak a ako ho identifikovat'. V úvode kapitoly sa preto bližšie zaoberá pojmami vidiecky boháč a vidiecky kapitalista, ktoré sa v dobovom diskurze vyžívali synonymne s termínom kulak. V porovnaní s predchádzajúcim modelom sú však jeho charakteristické znaky menej členité. V osobe kulaka vznikol typ človeka, vidieckeho boháča, vyznačujúceho sa falošnost'ou, lenivost'ou a chamtivost'ou, ktorá sa s ciel'om zdôraznit' jeho negatíva kládla do jednej konštrukcie s pozitívnym hodnotením rol'níkov a robotníkov v družstvách. Častý obraz predstavoval motív vykorist'ovaných rol'níkov, ktorí mali pre kulaka zastupujúceho kapitalistickú triedu či buržoáziu na vidieku nižšiu hodnotu než hospodársky dobytok. Ďalším identifikačným a výrazne pertraktovaným znakom kulaka bola podl'a Nečasovej jeho snaha bránit' pokroku, modernizácii a vedecko-technickému rozvoju, a to bud' priamo - poškodzovaním pol'nohospodárskej techniky -, alebo nepriamo - sabotážou pri práci v JRD.

Nižšie, ale nemenej podstatné zastúpenie v pozícii nepriatel’a formujúceho sa socializmu mal katolícky kňaz. Autorka túto skupinu d'alej kategorizuje na vyššie duchovenstvo, vlasteneckých kňazov, nesúhlasiacich kňazov, rehol'níkov a cirkevných predstavitel'ov Vatikánu. 
Zdôrazňuje sa ich depersonalizácia a homogenizácia, ked’že kňazi v dobovom diskurze nefigurovali jednotlivo, ale skôr v podobe kolektívu. Najpozitívnejší obraz prezentovali vlasteneckí kňazi v rámci nižšieho kléru, ktorý často vystupoval ako mravný a režimu lojálny protiklad vyššieho duchovenstva vrátane Vatikánu, spájaného s militantnými postojmi, túžbou po moci a sympatiami s kapitalistickým Západom. Pozitíva nižšieho kléru sa prejavovali v jeho spolupráci s režimom, čo bolo v dobovom vnímaní charakterizované nasledovne: „Přívlastku vlastenecký kněz se dostalo těm kněžím, kteří pochopili snahu doby, tužby národa a uměli je ve skvělé synthesi snoubit s věcmi duchovními" (s. 143). Vo vzt'ahu náboženstva a ideológie sa často vyskytoval obraz Krista ako prvého socialistu a s tým spojená analógia kňaza v pozícii robotníka. Zámerom uvedenej reflexie bolo vyjadrit' kompatibilitu dvoch ideových systémov vychádzajúcich z rôznych základov. Nečasová poukazuje na to, že v skúmanom období sa $\mathrm{v}$ oficiálnom diskurze venovala pozornost' primárne spoločným prvkom a akékol'vek negatíva či odlišnosti tohto vzt'ahu boli zatlačené do úzadia. K negatívnejšej reflexii dochádzalo pri skupine nesúhlasiacich kňazov, ktorí odmietli spolupracovat's režimom a boli označení za „nohsledy biskupů a Vatikánu“ (s. 152). V skúmanom období im nebol venovaný väčší priestor, čo vysvetl'uje iba krátku zmienku o nich v podobe pol stranovej podkapitoly. Väčší záujem mal režim o rehol'níkov, ktorí sa dostali do verejného diskurzu v spojení s politickými procesmi a akciou K. V súvislosti s tým sa vytrácajú ich pozitívne atribúty a po roku 1950 už vystupujú v pozícii nepriatel’a.

Posledným prezentovaným modelom sú Spojené štáty americké, ktoré možno považovat' za zastrešujúci prvok všetkých menovaných aj nemenovaných skupín ideologických oponentov socializmu. Nečasovej výskumy potvrdzujú, že každý, kto bol v tom čase označený za nepriatel'a mal isté prepojenie či kontakt na Spojené štáty americké, a to či už fyzicky, alebo v ideovej rovine. V rámci tohto konceptu je prítomný silný negatívny postoj, pozitívna reakcia je v danej dobe skôr výnimkou. Išlo o najfrekventovanejší koncept nepriatel’a, ktorý vystupoval ako protipól k Sovietskemu zväzu a socializmu, čiže „USA tak představuje symbolické ústředí spletité zrady, spiknutí a agrese vưči nově budovanému socialismu" (s. 162). V tejto kapitole sa autorka zameriava na niekol'ko základných motívov, ktoré prispeli k vytváraniu obrazu nepriatel'a - zarad'uje k nim príbeh o oslobodení Československa, explicitnú odlišnost' USA ilustrovanú, okrem iného, tzv. americkým spôsobom života a v neposlednom rade zohl'adňuje tiež kontext americkej politiky.

Obraz oslobodzovania Československa po 2. svetovej vojne bol v súvislosti so zapojením USA reinterpretovaný po februárovom prevrate v roku 1948. Účast' amerických vojsk sa minimalizovala, resp. úplne 
vymizla a nahradila ju teória o snahe podmanit’ si Československo, ktoré od tohto osudu zachránila Červená armáda. Amerika bola domácej verejnosti prezentovaná ako prostredie „úpadku, degenerace a katastrofy“"založené na „esenciálně špatné bázi, v jejich [Spojených štátov amerických, $\mathrm{PM}$ ] centru je něco ,zkaženého'“(s. 170). Diferencializácia a esencializácia západnej vel'moci ako ontologicky protichodného protivníka sa budovala na bytostnej odlišnosti anglosaskej rasy voči slovanstvu. Využívaným motívom poukazujúcim na falošnost' obrazu Ameriky ako stelesnenia demokracie a liberalizmu bol fakt, že americký občan emigroval do socialistického Československa v snahe nájst’ skutočnú demokraciu. Nečasová analyzuje tento prvok na základe výskytu správ o americkom emigrantovi G. Wheelerovi. V závere konštatuje, že obraz, ktorý verejnosti predkladal oficiálny diskurz v rokoch 1948 - 1956 prezentoval Spojené štáty americké nachádzajúce sa „ve fázi hlubokého společenského a morálního úpadku, projevujícího se sociálněpatologickými jevy, např́klad delikvencí, prostitucí, alkoholismem" (s. 206). Prejavom degenerácie národa sa stala aj jeho kultúra, tvoriaca súčast' obrazov o živote Ameriky, ale najdominantnejšie postavenie vo vzt'ahu k Československu predstavovali zahraničnopolitické aktivity USA. Tie sa spájali nielen s reinterpretáciou fašistického obdobia v Európe, ale najmä s rozširovaním militantných kapitalistických, imperialistických a koloniálnych tendencií, ktoré ohrozovali svetový mier presadzovaný v oficiálnej rétorike mierumilovným Sovietskym zväzom a d'alšími socialistickými krajinami. V tomto smere sú Spojené štáty americké ako jediný z predložených modelov stvárnené na princípe nielen dehumanizácie, ale aj démonizácie. Stotožňovali sa s chobotnicou, vlkom či pijavicou predstavujúcimi protiklad $\mathrm{k}$ civilizácii, kultúre a l’udskosti. Princíp démonizácie sa ilustroval v konštrukcii nepriatel'a, ktorý je „transformován do mýtického hrůzného subjektu páchajícího zlo, jež překračuje všechny myslitelné hranice" (s. 198).

Spoločným faktorom jednotlivých modelov, ktoré Nečasová vo svojej publikácii priblížila je istý stupeň generalizácie. Autorka sa nezameriava na jednotlivcov, ktorí vystupovali proti režimu, ale skúmaním rozsiahleho korpusu textov rôznych žánrov nachádza spoločné paralely, charakteristické vlastnosti a zjednocujúce ideové zázemie vybraných skupín obyvatel'stva, na základe ktorých predkladá model nepriatel'a socialistického režimu tak, ako ho vnímala doba. Je potrebné upozornit' na to, že uvedené modely politicko-ideologických oponentov neboli statickými obrazmi v dobovom diskurze. Vyvíjali a modifikovali sa tak, ako sa menili spoločensko-politické podmienky. Axiologický prístup k nim sa pohyboval na osi od pozitívneho k negatívnemu, resp. od zlého k horšiemu v závislosti na kontexte. Zhodnými charakterovými 
vlastnost'ami zaznamenanými u všetkých analyzovaných nepriatel'ov je lenivost', chamtivost', sebectvo a bezcitnost', ale aj nemorálnost', falošnost' a nelojálnost'. Rámcujúcim faktorom nepriatel'stva voči socializmu boli sympatie s kapitalizmom a vykorist'ovanie, ktoré zároveň mravne a morálne vyzdvihovali socializmus, resp. krajiny socialistického bloku. Nečasová tento faktor charakterizuje ako prejav „celkové sovětizace tehdejší společností" (s. 211).

V závere publikácie autorka predkladá syntetizujúce zhodnotenie výsledkov výskumu, v ktorom sa opätovne vracia k ciel'om a teóriám stanoveným na začiatku. Ked'že v jadre venuje pozornost' najmä konkrétnej analýze, v závere usúvzt’ažňuje zistené poznatky s teoretickým stupňami procesu konštrukcie nepriatel'a, ktoré vymedzila v prvej kapitole. Identifikuje tiež štyri základné funkcie nepriatel'a v spoločnosti - identitotvornú, hierarchizujúcu, mobilizujúcu a legitimizujúcu, ktoré možno priebežne identifikovat' už v jednotlivých analýzach. Denisa Nečasová konštatuje, že ku koncu sledovaného obdobia sa počet obrazov nepriatel'a v oficiálnom diskurze znižuje, čo odôvodňuje postupnou stabilizáciou spoločenských pomerov, ústupom od revolučných a radikálnych tendencií spojených s februárovým prevratom a zmiernením konfrontačnej domácej i zahraničnej politiky. Jej tvrdenie súvisí so vstupným predpokladom, že koncept nepriatel'a je príznačný pre formujúce obdobie spojené s istou krízou, prevratom či nástupom nového zriadenia, systému alebo s personálnou výmenou.

Na záver môžeme vyjadrit' presvedčenie, že recenzovaná publikácia Denisy Nečasovej predstavuje zaujímavý, aktuálny, kompetentne a erudovane spracovaný príspevok k problematike výskumu obdobia socializmu v jeho raných fázach. Kniha Obrazy nepř́tele v Československu 1948 - 1956 je podnetným a inšpiratívnym čítaním pre záujemcov o túto tému či obdobie, ktorá môže prispiet' k rozšíreniu poznatkov v mnohých vedných odboroch, nielen v rámci histórie. Pútavo napísaný text obsahujúci množstvo informácií z oblasti dejín, politiky aj kultúry nepochybne nájde využitie nielen medzi členmi vedeckej komunity, ale aj u záujemcov z radov širšej verejnosti. 